\title{
Digital Technology as A Teaching Strategy in COVID-19
}

Francisco Mayron Morais Soares ${ }^{1 *}$, Kirley Kethellen Batista Mesquita ${ }^{2}$, Camilo Hugo Freitas Andrade $^{3}$, Francisco Luan de Sousa Braga ${ }^{4}$, Aléxia Éllen Albuquerque Farias ${ }^{5}$, Glaucirene Siebra Moura Ferreira ${ }^{6}$

${ }^{T}$ Nurse. Master in Nursing. Associate Professor at Faculdade UNINTA Itapipoca. Leader of the Research Group on Advanced Practices and Technologies in Nursing - GEPATE.

${ }^{2}$ Nurse. Master's student in Nursing from the Federal University of Ceará. Member of the Research Group on Advanced Practices and Technologies in Nursing - GEPATE

${ }^{3,4,5}$ Graduating in Nursing. Member of the Research Group on Advanced Practices and Technologies in Nursing GEPATE

${ }^{6}$ Nurse. PhD student in Coeltive Health. Coordinator of the Nursing Course at Faculdade UNINTA Itapipoca

*Corresponding Author

Francisco Mayron Morais Soares

\section{Article History}

Received: 22.08 .2020

Accepted: 29.08 .2020

Published: 17.09.2020

\begin{abstract}
Objective: Reflect on the use of digital technology as a teaching strategy to face the pandemic. Method: Reflective study. Results: The study allowed reflections on the use of digital technologies for the teaching and learning process in order to reduce the damage caused by the pandemic. Final considerations: This reflection can contribute to rethinking about digital technologies as a teaching strategy to face the pandemic.
\end{abstract}

Keywords: Nursing Education, Technology, Remote Teaching, Covid-19.

\section{INTRODUCTION}

The constant social and epidemiological changes directly impacted the conditions on account of Coronavirus Disease 2019 - (COVID-19), attributed to the education and health services the demand to develop continuous educational strategies, which make it possible to respond to the needs of continuity for the functioning of the services . Until mid-March 2020, academic procedures were following the normal flow, butin this, the World Health Organization classified COVID-19 as a pandemic $[1,2]$

In this context, as well as other emerging infectious diseases, COVID-19 is transmitted by respiratory droplets and by direct contact with an infected person and as a strategy to contain the rapid spread of viruses, services and the population have adopted rigorous changes, configuring themselves with a public health problem [2].

In June 2020, approximately 7.6 million people were confirmed worldwide with the virus and more than 400 thousand deaths, which causes a high lethality rate [3]. Following the guidelines of the World Health Organization, underdeveloped countries such as Brazil, which had high patient rates, implemented urgent biosafety measures as a containment strategy and possible stabilization of cases [1,3].

Due to the rapid increase in the epidemic degree, as transmission also comes from interpersonal relationships, simple measures were suggested, such as hand hygiene (with water and soap or 70\% alcohol), wearing masks, protecting your nose and mouth when sneezing or coughing, in addition to social distance. Such measures were used and are focused on reducing virus transmission $[4,5]$.

As the educational system could not stop, activities would have to be maintained and students would not be harmed, learning through technology was the most viable strategy found to reduce the impact of the pandemic [6].

Copyright @ 2020: This is an open-access article distributed under the terms of the Creative Commons Attribution license which permits unrestricted use, distribution, and reproduction in any medium for non commercial use (NonCommercial, or CC-BY-NC) provided the original author and source are credited. 
Nevertheless, the Virtual Learning Environment (VLE), presented itself with a moldable strategy, and remote teaching transcends personal involvement, and made access viable, effective and, above all, tends to reduce the losses of academic activities in higher education. .

It is important to understand that the remote teaching process in this pandemic period is temporary, but the adequacy of the continuity of activities previously planned in person must continue, because due to the crisis, the most viable strategy for reducing losses was this and should be done with the same principles as in-person classes [7].

Given the above, this study aimed to reflect on the use of digital technology as a teaching strategy to face the pandemic.

\section{METHOD}

Reflective study, for which the literature review was carried out, aiming to gather knowledge about the topic under study, integrating it and facilitating its accumulation [8].

Due to the incipience of the theme, it was decided to include in the literature articles and manuals that had the theme. The search took place in the databases: Nursing Database (BDENF), National Library of Medicine and National Institutes of Health (PUBMED / Medline), Cumulative Index of Nursing and Allied Health Literature (CINAHL), Web of Science, Excerpta Medica dataBASE (EMBASE), Scientific Electronic Library Online (SciELO) and Cochrane through the following crossing: "Nursing Education" and "Technology" and "Remote Education" "Covid-19".

The inclusion and exclusion criteria for the research were established, considering the following types of studies: 1) articles on the theme covid-19;2) to approach digital technology for teaching, without time and language restrictions.

The search proceeded by the following steps, initially the readings of the titles of the articles that contemplated the aforementioned criteria were carried out, then the reading of the abstracts of the articles was carried out and then the articles were read in full to, in fact, include in the study the works that answered the research question.

The proposed reflections were based on the light (mainly) of the national literature related to the theme. The presentation of explanations and reflections to be made was in the form of guiding axes on the theme, arising from interpretations of the literature and reflective impressions of the authors. These interpretations were driven by an understanding of the theme at the global level, that is, the "state of the art". Furthermore, as there was no direct / applied research interaction, the need to submit the study to ethical procedures was excluded.

As recommended by Resolution 510/2016 of the National Health Council, which involves researched with public domain data, the study was conducted.

\section{REFLECTIVE ANALYSIS}

The study allowed reflections on the use of digital technologies for the teaching and learning process in order to reduce the damage caused by the pandemic. Such a scenario directly impacted the scenario of educational institutions, and emerges as a necessary attention in what concerns the theme. For this, two reflective categories were divided.

\section{Teaching difficulties in the time of covid-19}

Due to the difficulties arising from the pandemic, with social distancing measures, the face-to-face classes were suspended, but as an educational strategy, we opted so quickly for remote education that consists of educational education through digital means, of these, there are two that stand out the most the recorded and synchronous classes, previously recorded classes are made available in a virtual environment, while in synchronous classes the class takes place in real time and there is an interaction between teacher and student $[9,10]$.

For teaching in the current modalities, it was necessary to adapt both the teacher and the student, where the teacher would systematically continue to teach the classes remotely and the student would do the activities with the delivery of established deadlines. Therefore, in theory, the same rigor of in-person quality should be maintained, however, technical and cognitive difficulties have impacted the performance of the teaching and learning process [6, 7].

In this last time, with the remote classes, the technological revolution presented important aspects to be mentioned, such as the difficulties of accessing the internet, as not all students have such a service; access to computers, most students have only mobile phones, which makes it difficult to access and carry out activities, the inconsistent 
quality of the internet used; students who do not have any type of device, with that, they end up locking or giving up on the course $[11,12]$.

In order to guide the pre-existing teaching experience, the pandemic caused an expansion of possibilities like remote teaching, which required teachers to experience a transformation, a recreation, a reformulation and a resignification of the teaching and learning process. In addition, remote teaching is similar in content, but totally different in the format presented. In recent years, these spaces have grown, but not all were prepared for changes, therefore, the difficulty of readaptation in the teaching process has become a real professional conflict [11].

Thus, the other reflective context is inserted, which deals with which technologies are used to assist in the teaching and learning process.

\section{Technologies used for remote education}

The current pandemic has meant that traditional education has become remote, thus, for the construction of knowledge in a non-face-to-face manner, the use of digital information and communication technologies has been implemented. Therefore, it is an aid in the teaching and learning process, not seen as a form of substitution, but as a technology that can contribute to the improvement of the other [11].

Next, some technologies and their respective functions will be exposed.

Table-1: Examples of platforms used for remote education. Brazil, 2020

\begin{tabular}{|l|l|l|}
\hline Platform & Functions and Benefits & Limitations \\
\hline Google Meet & $\begin{array}{l}\text { Easy Installation; can be used without internet; class can be } \\
\text { recorded, you can mirror the content screen }\end{array}$ & $\begin{array}{l}\text { Restricted access to non- } \\
\text { subscribers. }\end{array}$ \\
\hline Zoom Platform & Easy installation; videoconferences; screen sharing; & $\begin{array}{l}\text { Restricted access for free, and } \\
\text { depends on the chosen plan to } \\
\text { obtain more functions. }\end{array}$ \\
\hline Flipgrid & $\begin{array}{l}\text { It is a very intuitive digital platform in which the teacher } \\
\text { generates a link, launches a challenge or a question and sends } \\
\text { it to students. }\end{array}$ & Limited time for resource use. \\
\hline $\begin{array}{l}\text { Blackboard } \\
\text { Collaborate }\end{array}$ & $\begin{array}{l}\text { It is a tool of the virtual learning environment. It is a web } \\
\text { conferencing tool capable of reproducing a traditional } \\
\text { classroom for the use of active methodologies. }\end{array}$ & Paid service \\
\hline
\end{tabular}

Therefore, such tools contribute to a better continuity of the activities scheduled at the beginning of the semester. However, as already mentioned, the difficulties make the process more complex.

Access to technologies allowed student teacher interaction, in an interactive, flexible and decentralized way. With the possibility of recording the classes, the student who had a problem can attend later, being, therefore, a determinant in the spread of knowledge and teaching.

This is due to the extreme programmatic vulnerability, which compromises the conditions of provision, minimum conditions to guarantee the quality of life, maintenance and prevention of necessary, effective and democratic social resources, and becomes a major problem, since numerous factors influence the acquisition of this equality 13 .

Some studies reflect on the factors that influence low or non-adherence to remote access, and such limitations generate great impacts in several theoretical hubs $[13,14]$.

Nevertheless, it is worth considering that such a pandemic phenomenon is temporary, although there are only estimates of its duration. Such a study contributes to a better understanding of the use of digital technologies for the teaching and learning process. And it is understood that the damage is great, but over time, normalization processes will occur.

In view of the rapid expansion of remote education, it is up to the institutions to offer services that contribute to the continuity of the teaching and learning process. Although challenging, the pandemic exposes the teacher and a situation of expanding learning with active methodologies. 


\section{STUdy Limitations}

Due to the type of study presented, it is prudent to state that the reflections described, in a way, naive or just optimistic, cannot be taken as absolute truths, since, in a qualitative way we understand the state of the art, there is a limitation in the impossibility of to affirm, yet, about any benefit or change in remote education. Therefore, a larger study is recommended to assess the performance at the national level.

\section{Final Considerations}

It is understood that this difficult pandemic period has caused impacts on teachers and students, but that it has also led to the adherence of other methodologies that contributed to the development of their use.

Furthermore, it should be noted that the main factors are mainly related to the economic, social and technological situation. And it is believed that, after this period of pandemic, educational measures will be implemented to avoid possible future disorders.

Finally, this study does not intend to finalize the discussions on the theme, but to encourage critical reflections about digital technology in facing the pandemic.

\section{REFERENCES}

1. World Health Organization (WHO). (2020). Health workers exposure risk assessment and management in the context of COVID-19 virus. [Internet]. Geneva: WHO; 2020 [accessed 06 Jun 2020]. Available in: https://apps.who.int/iris/bitstream/handle/10665/331340/WHO-2019-nCov-HCW_risk_assessment- 2020.1eng.pdf? Sequence $=1 \&$ isAllowed $=\mathrm{y}$

2. Morens, D. M., Daszak, P., \& Taubenberger, J. K. (2020). Escaping Pandora's box-another novel coronavirus. New England Journal of Medicine, 382(14), 1293-1295.

3. PAHO / WHO Brazil - Fact sheet - COVID-19 (disease caused by the new coronavirus), PAHO / WHO [Internet]. Pan American Health Organization / World Health Organization. 2020 [cited 4 June 2020]. Available from: https://www.paho.org/bra/index.php?option=com_content\&view=article\&id=6101:covid19\&Itemid=875

4. Gasmi, A., Noor, S., Tippairote, T., Dadar, M., Menzel, A., \& Bjørklund, G. (2020). Individual risk management strategy and potential therapeutic options for the COVID-19 pandemic. Clinical Immunology, 108409.

5. Cheng, V. C., Wong, S. C., Chen, J. H., Yip, C. C., Chuang, V. W., Tsang, O. T., ... \& Yuen, K. Y. (2020). Escalating infection control response to the rapidly evolving epidemiology of the Coronavirus disease 2019 (COVID-19) due to SARS-CoV-2 in Hong Kong. Infection Control \& Hospital Epidemiology, 41(5), 493-498.

6. Barros, L. (2020). Innovation in higher education as a coating strategy for COVID-19. Revista Expressão Católica Saúde. 5(1):3.

7. Charles, H. (2020). The Difference Between Emergency Remote Teaching and Online Learning [Internet]. 2020 [cited 15 June 2020]. Available from: https://er.educause.edu/articles/2020/3/the-difference-between-emergencyremote-teaching-and-online-learning

8. Polit, D. F., Beck C. T, Hungler B. P. H., \& Thorell, A. (2018). Fundamentals of Nursing Research. Porto Alegre: Artmed; 9th ed.

9. Gonçalves, E., \& Marco, F. (2020). The use of Digital Technologies in the initial training of Mathematics teachers in distance learning. Profession Magazine. 20(43): 1-15.

10. Ludovico, F. M., Machado, A. D., \& Barcellos, P. D. (2019). The pedagogical use of interactive digital presentation software (SADI) for the mediation of distance classes in synchronous mode. InterLetras. 8(30):1-14.

11. Carmo, R., \& Franco, A. (2019). From presential teaching to online teaching: learning from university teachers in distance education. Education in Review. 35.

12. Vargas, B., \& Nicolaides, C. (2019). Online classes and conflict as a tool for learning and transformation. The Especialist. 40(1).

13. Sposati, A. (2020). COVID-19 Reveals the Unequal Living Conditions of Brazilians. Social NAU. 11(20):101.

14. Farias, M., \& Leite Junior, J. (2020). Social vulnerability and COVID-19: considerations from social occupational therapy. 